•研究报告・

\title{
我国寒温带至亚热带森林多孔菌区系和多样性比较
}

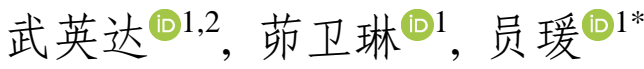

1. 北京林业大学生态与自然保护学院微生物研究所, 北京 100083; 2. 中国消防救援学院, 北京 102202

摘要: 多孔菌是木材腐朽菌的重要类群, 具有重要的生态功能和经济价值。本文比较分析了我国寒温带至亚热带的阿尔泰山 脉、秦岭山脉和南岭山脉的多孔菌物种、生态习性和区系特征。经调查, 在三个山脉共发现多孔菌8目29科107属287种, 其中 阿尔泰山、秦岭和南岭分别为84种、132种、160种，优势科均为多孔菌科和锈革孔菌科。三个山脉的共有属和共有种分别为 25 个和 14 个。区系地理分析发现，阿尔泰山脉和秦岭山脉以世界广布成分和北温带成分为主，南岭山脉以世界广布和泛热带 成分为主。在寄主选择性方面, 阿尔泰山脉的多孔菌偏好生长在裸子植物上, 其比例高于被子植物, 而秦岭和南岭则相反。 在腐朽类型方面, 从寒温带至亚热带白腐真菌物种数量呈现逐渐上升的趋势, 而褐腐真菌数量逐渐下降。通过比较分析 3 个不 同气候带的多孔菌物种多样性、寄主偏好性和引起的腐朽类型, 发现气候和植被类型是影响多孔菌区系组成的主要因素。 关键词: 多孔菌; 物种多样性; 区系; 分布特征

武英达, 芇卫琳, 员瑗 (2021) 我国寒温带至亚热带森林多孔菌区系和多样性比较. 生物多样性, 29, 1369-1376. doi: 10.17520/biods.2021094. Wu YD, Mao WL, Yuan Y (2021) Comparison of polypore florae and diversity from temperate to subtropical forest zones in China. Biodiversity Science, 29, 1369-1376. doi: 10.17520/biods.2021094.

\section{Comparison of polypore florae and diversity from temperate to subtropical forest zones in China}

Yingda Wu ${ }^{(\mathbb{D} 1,2}$, Weilin Mao ${ }^{(\mathrm{D} 1}$, Yuan Yuan ${ }^{(\mathrm{D}){ }^{*}}$

1 Institute of Microbiology, School of Ecology and Nature Conservation, Beijing Forestry University, Beijing 100083

2 China Fire and Rescue Institute, Beijing 102202

\section{ABSTRACT}

Background: Polypores are an important group of wood-decaying fungi and have important ecological functions and economic values. The unique geographical structure and complex vegetation types in China provide abundant substrates for the growth of polypores. Although the taxonomy of polypores has been well studied in China, few comparative studies on the diversity and flora of polypores among different climatic zones has been performed. This study is intended to compare the florae and populations of polypores in multiple forest zones with different climates and vegetations, and will provide the basis for the protection of species diversity and the development of application potential of polypores.

Methods: In this study, we comparatively analyzed the polypore species, ecological habits and floral characteristics in the Altai Mountains, the Qinling Mountains and the Nanling Mountains which are respectively located in boreal, temperate and subtropical zones in China.

Results: A total of 287 poroid wood-decaying fungal species belonging to 107 genera, 29 families, and 8 orders were obtained from the three mountain ranges. Of these species, 84, 132 and 160 were found in the Altai Mountains, the Qinling Mountains and the Nanling Mountains, respectively, and the community was dominated by families Polyporaceae and Hymenochaetaceae. In the generic and species levels, 25 genera and 14 species were common in the three mountain ranges. Floristic analysis found that polypores in the Altai Mountains and the Qinling Mountains were dominated by the cosmopolitan and the northern temperate elements, while polypores in the Nanling Mountains were dominated by the cosmopolitan and the pantropical taxa. In terms of host preference, polypores in the Altai Mountains preferentially grow on gymnosperms over angiosperms, while the opposite was true in the Qinling Mountains and

收稿日期: 2021-03-12; 接受日期: 2021-05-21

基金项目: 国家自然科学基金(32000010)

* 通讯作者 Author for correspondence. E-mail: yuanyuan1018@bjfu.edu.cn 
Nanling Mountains. In the two rotting types caused by polypores, the species number of white rot polypores increased, but that of the brown rot decreased, gradually from boreal to subtropical zones.

Conclusion: Climate and vegetation types are the major influencing factors on the flora composition of polypores, based on the analysis of species diversity, host preference and decaying type of polypores in the three mountains.

Key words: polypores; species diversity; floral composition; distribution character

多孔菌是木生担子菌中子实层体为孔状的种 类, 生长在活树、死树、倒木、腐朽木、树木根部 甚至地生, 可降解木材中的木质素、纤维素和半纤 维素, 造成木材白色或褐色腐朽, 在碳循环和养分 循环过程中起着不可替代的作用, 是森林生态系统 的物质循环和能量流动以及维持森林生态系统的 动态平衡的重要类群 (魏玉莲和戴玉成, 2004; Baldrian \& Lindahl, 2011; 戴玉成, 2012; Floudas et al, 2012; 周丽伟和戴玉成, 2013)。多孔菌与人类的 生活也息息相关, 其中很多种类是重要的林木病原 菌, 特别是经营林分的病原菌(Dai et al, 2007; 戴玉 成, 2012), 还有一些多孔菌如灵芝 (Ganoderma lingzhi)和桑黄(Sanghuangporus sanghuang)等是著 名的药用菌(戴玉成和杨祝良, 2008), 部分多孔菌如 灰树花(Grifola frondosa) 等是重要的食用菌(戴玉成 等, 2010)。近年来的研究发现有些多孔菌在环境治 理、生物修复和工业生产等领域也具有广泛应用价 值(Asiegbu et al, 2005; Dai et al, 2007; Cao et al, 2012; 戴玉成等, 2013; 王豪等, 2021)。

过去国内对多孔菌的物种多样性进行了系列 研究(崔宝凯等, 2006; 戴玉成等, 2006; Dai, 2012; Wu et al, 2020; 戴玉成等, 2021), 但对多孔菌的生 态学、区系组成和生态习性等研究还不够深入和系 统, 主要是某一类群或某一区域多样性研究中对区 系进行初步讨论, 很少对不同区域的多孔菌类群和 区系组成进行比较研究(李玉和图力古尔, 2000; Zhou et al, 2011; Li et al, 2014; 边禄森和戴玉成, 2015; 王小燕和魏玉莲, 2015)。中国地域广阔, 从北 至南包括了寒温带、温带、暖温带、亚热带和热带 地理区域, 同时中国又是北半球木本植物种类最丰 富的国家, 具有寒温带针叶林、温带针阔混交林和 热带雨林等植被类型, 几乎包括了北半球的所有植 物区系成分, 独特的地理结构和复杂的植被类型孕 育了丰富的多孔菌资源(周丽伟和戴玉成, 2013)。对 不同气候带和植被类型下多孔菌的分布和区系组 成进行研究, 不仅能够全面了解多孔菌的生长规 律、生态习性和分布特征, 而且对多孔菌物种多样
性的保护和应用开发也有重要的参考价值。本文对 我国寒温带到亚热带地区的多孔菌区系进行比较 研究, 调查区域为寒温带的阿尔泰山脉、温带的秦 岭山脉以及亚热带的南岭山脉，以揭示不同气候带 和植被类型对多孔菌物种组成和区系特征的影响。

\section{材料与方法}

\section{1 研究区域}

阿尔泰山脉位于新疆北部, 呈西北-东南走向, 属于温带大陆性季风气候, 年均气温 $-4^{\circ} \mathrm{C}$ 至 $3^{\circ} \mathrm{C}$, 年均降水量300-500 mm。植被垂直分布明显, 由下 而上为山地亚沙漠带、山地草原带、山地森林带和 高山带, 共计有种子植物 94 科 528 属 1,491种, 其中 重要成林树种为新疆落叶松(Larix sibirica)、新疆云 杉(Picea obovata)、垂枝华(Betula pendula)和山杨 (Populus davidiana)等(陈文俐和杨昌友, 2000; 曹秋 梅等, 2015; Hu et al, 2018; Ye et al, 2018)。调查地点 包括：喀纳斯国家级自然保护区、白哈巴国家森林 公园、贾登峪国家森林公园、阿勒泰小东沟森林公 园等。植被类型以寒温带种类为主。

秦岭山脉位于中国中部, 东西走向, 地处温带 与亚热带过渡区, 是中国气候带的南北分界线, 年 均气温 $-3^{\circ} \mathrm{C}$ 至 $16^{\circ} \mathrm{C}$, 年均降水量 600-1,200 mm (马 新萍, 2015)。秦岭巨大的海拔高度差使植被分布具 有明显的垂直带谱 ${ }^{\circledR}$, 由上而下为高山草甸带、针叶 林带、山地针阔混交林带、山地落叶阔叶林带、常 绿阔叶林带, 其中种子植物有154科950属3,539种 ${ }^{2}$, 主要成林树种为云杉(Picea asperata)、冷杉(Abies fabri)、油松 (Pinus tabuliformis)、红华 (Betula albosinensis)、锐齿栋(Quercus aliena)和华山松 (Pinus armandii)等(岳明, 2015; 赵婷等, 2019)。调查 地点包括: 佛坪自然保护区、华山、化龙山自然保 护区、骊山、牛背梁国家级自然保护区、秦岭植物

(1) 陈倩 (2019) 秦岭山地天然次生林群落物种多样性与功能多样性研 究. 硕士学位论文, 西北农林科技大学, 西安.

(2) 李婷 (2018) 秦岭种子植物物种多样性与主要功能性状的海拔格局 基于区系数据库. 硕士学位论文, 西北大学, 西安. 
园、太白山国家森林公园和周至国家级自然保护区 等。植被类型以温带种类为主。

南岭位于中国东南部, 兼具典型的亚热带温湿 气候和亚热带季风气候, 又因地势较高而具有山地 气候特色, 年均气温 $15-21^{\circ} \mathrm{C}$, 年均降水量 1,200-1,500 mm, 是我国亚热带地区物种最丰富的 区域, 也是全球同纬度地区森林植被的典型代表, 包括亚热带高山湖泊植被、亚热带山地草坡、亚热 带竹林、亚热带常绿针阔混交山顶矮林、亚热带常 绿针阔叶混交林、亚热带常绿与落叶阔叶混交林、 亚热带常绿阔叶山顶矮林和亚热带常绿阔叶林等 多种植被类型，其中种子植物有203科1,211属4,167 种(董安强等, 2012; 王瑶, 2017 ${ }^{\circledR}$; 宋斌等, 2018; 缪 绅裕等, 2020)。调查区域包括广东省车八岭国家级 自然保护区、丹霞山森林公园、南岭国家级自然保 护区和湖南莽山国家森林公园。植被类型以亚热带 为主。这三个山脉基本是从西北过渡至东南, 纬度 和距离也呈梯度排列。

\section{2 研究方法}

研究材料来源于本团队过去 20 年对研究区域 的多次野外考察, 详细记录了多孔菌的寄主、发生 频率、生态习性、腐朽类型和所在植被类型等生态 数据。所有标本保存在中国科学院沈阳应用生态研 究所和北京林业大学微生物研究所标本馆, 总计 3,200 余号。结合宏观和微观特征进行多孔菌物种鉴 定的方法参照Dai (2010), 腐朽类型、发生频次划分 参考Dai (2012)、地理成分分析参考 Ryvarden和 Gilbertson (1993)。采用Origin 2021 (https://www.ori ginlab.com/)软件绘制韦恩图和热图。

\section{2 结果}

\section{1 多孔菌物种多样性}

根据野外调查和室内鉴定结果, 三个山脉共发 现多孔菌287种(附录1), 隶属8目29科107属(表1), 其中阿尔泰山有多孔菌6目19科50属84种, 秦岭有 6 目 21 科 64 属 132 种, 南岭有 6 目 22 科 75 属 160 种, 多 孔菌的物种多样性从寒温带到亚热带逐渐升高。

如图1A所示, 三个山脉的共有多孔菌种类为 16 种, 隶属于 14 个属。特有多孔菌种类阿尔泰山脉

(1) 王瑶 (2017) 南岭三种主要森林类型土壤甲烷通量研究. 硕士学位 论文, 中南林业科技大学, 长沙.
有 40 种、秦岭有 66 种、南岭有 114 种, 分别占各山脉 多孔菌物种总数的 $47.6 \% 、 50.0 \%$ 和 $71.3 \%$ 。比较三 个山脉多孔菌属的区系组成发现共有属 25 个, 阿尔 泰山脉和秦岭山脉特有属各 9 个, 南岭山脉特有属 32 个(图1B)。多孔菌的特有种比例从寒温带至亚热 带逐渐增高, 表现出明显的地域差异。

\section{2 优势科属分析}

根据各科包含的多孔菌属、种的数量分析得出 (表1和图2), 三个山脉中多孔菌科和锈革孔菌科的 种类最为丰富, 其中阿尔泰山脉分别有 19 种和 17 种、秦岭山脉有 37 种和 30 种、南岭各 45 种, 占各山 脉物种数量的比例为 $42.9 \% 、 50.8 \%$ 和 $56.3 \%$ 。

根据物种数量, 阿尔泰山的优势属依次为薄孔 菌属(Antrodia)、栓孔菌属(Trametes)、泊氏孔菌属 (Postia); 秦岭的优势属为栓孔菌属、泊氏孔菌属和多 孔菌属(Polyporus); 南岭的优势属依次是多年卧孔菌 属(Perenniporia)、栓孔菌属、褐卧孔菌属(Fuscoporia)。 其中栓孔菌属为三个山脉的共有优势属。

\section{3 生态习性分析}

根据研究结果, 除集毛孔菌属(Coltricia)和小 集毛孔菌属(Coltriciella)为可能的共生菌根真菌外, 其他种类均为木材腐朽真菌, 根据造成木材腐朽的 类型不同可划分为白腐真菌和褐腐真菌, 阿尔泰山 脉、秦岭山脉和南岭山脉的白腐真菌种类依次为 57 种、107种和139种, 褐腐真菌的种类为27种、25种 和11种。可明显看出阿尔泰山脉至南岭山脉白腐真 菌数量呈现逐渐增高的趋势, 而褐腐真菌数量逐渐 下降, 且白腐真菌数量远远高于褐腐真菌。

比较各山脉多孔菌的寄主发现(表2), 阿尔泰 山脉的多孔菌偏好生长在裸子植物上, 其比例高于 被子植物, 而秦岭和南岭则相反。其中, 阿尔泰山 脉的多孔菌生长在裸子植物上的物种丰富度最高, 占该山脉多孔菌物种总数的 $65.5 \%$; 南岭能够生长 在裸子植物上的多孔菌物种丰富度最低, 占比 $23.7 \%$, 但该山脉偏好被子植物的种类共 141 种, 超 过该地区多孔菌物种总数的 $85 \%$ 。

根据多孔菌的分布情况和出现频度可分为常 见种、偶见种和稀有种(Dai, 2012)。如图3所示, 阿 尔泰山脉、秦岭和南岭的稀有种、偶见种和常见种 的数量不同但比例相似, 其中, 阿尔泰山脉和秦岭 的常见种、偶见种和稀有种的组成比例更为接近。 
表1 三个山脉多孔菌物种多样性组成

Table 1 The compositions of polypores in the three mountain ranges

\begin{tabular}{|c|c|c|c|c|c|c|c|c|}
\hline \multirow[t]{2}{*}{ 目 Order } & \multirow[t]{2}{*}{ 科 Family } & \multirow{2}{*}{$\begin{array}{l}\text { 地理成分 } \\
\text { Geographical } \\
\text { element }\end{array}$} & \multicolumn{3}{|c|}{ 属数 Genus no. } & \multicolumn{3}{|c|}{ 种数 Species no. } \\
\hline & & & $\begin{array}{l}\text { 阿尔泰山脉 } \\
\text { Mt. Altay }\end{array}$ & $\begin{array}{l}\text { 秦岭山脉 } \\
\text { Mt. Qinling }\end{array}$ & $\begin{array}{l}\text { 南岭山脉 } \\
\text { Mt. Nanling }\end{array}$ & $\begin{array}{l}\text { 阿尔泰山脉 } \\
\text { Mt. Altay }\end{array}$ & $\begin{array}{l}\text { 秦岭山脉 } \\
\text { Mt. Qinling }\end{array}$ & $\begin{array}{l}\text { 南岭山脉 } \\
\text { Mt. Nanling }\end{array}$ \\
\hline \multirow{2}{*}{$\begin{array}{l}\text { 伞菌目 } \\
\text { Agaricales }\end{array}$} & 牛舌菌科 & 世界广布 & - & - & 1 & - & - & 1 \\
\hline & $\begin{array}{l}\text { Fistulinaceae } \\
\text { 小菇科 } \\
\text { Mycenaceae }\end{array}$ & $\begin{array}{l}\text { Cosmopolitan } \\
\text { 热带亚热带 } \\
\text { Subtropical to } \\
\text { tropical }\end{array}$ & - & - & 1 & - & - & 1 \\
\hline $\begin{array}{l}\text { 黑孢革菌目 } \\
\text { Amylocorticiales }\end{array}$ & $\begin{array}{l}\text { 黑孢革菌科 } \\
\text { Amylocorticiaceae }\end{array}$ & $\begin{array}{l}\text { 北温带 } \\
\text { Temperate }\end{array}$ & 1 & 1 & - & 2 & 1 & - \\
\hline $\begin{array}{l}\text { 木耳目 } \\
\text { Auriculariales }\end{array}$ & $\begin{array}{l}\text { 木耳科 } \\
\text { Auriculariaceae }\end{array}$ & $\begin{array}{l}\text { 世界广布 } \\
\text { Cosmopolitan }\end{array}$ & - & 1 & 1 & & 1 & 1 \\
\hline $\begin{array}{l}\text { 褐褶孔菌目 } \\
\text { Gloeophyllales }\end{array}$ & $\begin{array}{l}\text { 褐禇孔菌科 } \\
\text { Gloeophyllaceae }\end{array}$ & $\begin{array}{l}\text { 世界广布 } \\
\text { Cosmopolitan }\end{array}$ & 1 & 1 & 1 & 2 & 2 & 1 \\
\hline \multirow[t]{3}{*}{$\begin{array}{l}\text { 锈革孔菌目 } \\
\text { Hymenochaetales }\end{array}$} & $\begin{array}{l}\text { 锈革孔菌科 } \\
\text { Hymenochaetaceae }\end{array}$ & $\begin{array}{l}\text { 世界广布 } \\
\text { Cosmopolitan }\end{array}$ & 11 & 16 & 16 & 17 & 30 & 45 \\
\hline & $\begin{array}{l}\text { 锐孔菌科 } \\
\text { Oxyyporaceae }\end{array}$ & $\begin{array}{l}\text { 北温带 } \\
\text { Temperate }\end{array}$ & - & 1 & 2 & - & 4 & 8 \\
\hline & $\begin{array}{l}\text { 裂孔菌科 } \\
\text { Schizoporaceae }\end{array}$ & $\begin{array}{l}\text { 世界广布 } \\
\text { Cosmopolitan }\end{array}$ & - & 2 & 2 & & 4 & 5 \\
\hline \multirow{18}{*}{$\begin{array}{l}\text { 多孔菌目 } \\
\text { Polyporales }\end{array}$} & 齿毛菌科 & 世界广布 & 1 & 1 & 1 & 1 & 1 & 1 \\
\hline & $\begin{array}{l}\text { Cerrenaceae } \\
\text { 泪革孔菌科 } \\
\text { Dacryobolaceae }\end{array}$ & $\begin{array}{l}\text { Cosmopolitan } \\
\text { 北温带 } \\
\text { Temperate }\end{array}$ & 2 & 3 & & 7 & 10 & - \\
\hline & $\begin{array}{l}\text { 索孔菌科 } \\
\text { Fibroporiaceae }\end{array}$ & $\begin{array}{l}\text { 北温带 } \\
\text { Temperate }\end{array}$ & - & 1 & 1 & & 1 & 1 \\
\hline & $\begin{array}{l}\text { 拟层孔菌科 } \\
\text { Fomitopsidaceae }\end{array}$ & $\begin{array}{l}\text { 世界广布 } \\
\text { Cosmopolitan }\end{array}$ & 6 & 4 & 4 & 13 & 10 & 6 \\
\hline & $\begin{array}{l}\text { 灵芝科 } \\
\text { Ganodermataceae }\end{array}$ & $\begin{array}{l}\text { 世界广布 } \\
\text { Cosmopolitan }\end{array}$ & 1 & 1 & 2 & 2 & 2 & 4 \\
\hline & $\begin{array}{l}\text { 胶化孔菌科 } \\
\text { Gelatoporiaceae }\end{array}$ & $\begin{array}{l}\text { 北温带 } \\
\text { Temperate }\end{array}$ & 2 & 1 & - & 3 & 1 & - \\
\hline & $\begin{array}{l}\text { 树花孔菌科 } \\
\text { Grifolaceae }\end{array}$ & $\begin{array}{l}\text { 北温带 } \\
\text { Temperate }\end{array}$ & - & - & 1 & - & - & 1 \\
\hline & $\begin{array}{l}\text { 硬壳孔菌科 } \\
\text { Incrustoporiaceae }\end{array}$ & $\begin{array}{l}\text { 世界广布 } \\
\text { Cosmopolitan }\end{array}$ & 2 & 2 & 3 & 2 & 3 & 9 \\
\hline & $\begin{array}{l}\text { 囊耙齿菌 } \\
\text { Irpicaceae }\end{array}$ & $\begin{array}{l}\text { 世界广布 } \\
\text { Cosmopolitan }\end{array}$ & 2 & 5 & 5 & 2 & 9 & 9 \\
\hline & $\begin{array}{l}\text { 皱皮孔菌科 } \\
\text { Ischnodermataceae }\end{array}$ & $\begin{array}{l}\text { 北温带 } \\
\text { Temperate }\end{array}$ & 1 & 1 & - & 1 & 1 & - \\
\hline & $\begin{array}{l}\text { 硫磺菌科 } \\
\text { Laetiporaceae }\end{array}$ & $\begin{array}{l}\text { 北温带 } \\
\text { Temperate }\end{array}$ & 2 & 1 & 1 & 3 & 1 & 1 \\
\hline & $\begin{array}{l}\text { 皱孔菌科 } \\
\text { Meruliaceae }\end{array}$ & $\begin{array}{l}\text { 世界广布 } \\
\text { Cosmopolitan }\end{array}$ & 3 & 3 & - & 3 & 5 & - \\
\hline & $\begin{array}{l}\text { 原毛平革菌科 } \\
\text { hanerochaetaceae }\end{array}$ & $\begin{array}{l}\text { 世界广布 } \\
\text { Cosmopolitan }\end{array}$ & 1 & 1 & 3 & 2 & 2 & 3 \\
\hline & $\begin{array}{l}\text { 柄杯菌科 } \\
\text { Podoscyphaceae }\end{array}$ & $\begin{array}{l}\text { 热带亚热带 } \\
\text { Subtropical to } \\
\text { tropical }\end{array}$ & - & - & 1 & - & - & 1 \\
\hline & $\begin{array}{l}\text { 多孔菌科 } \\
\text { Polyporaceae }\end{array}$ & $\begin{array}{l}\text { 世界广布 } \\
\text { Cosmopolitan }\end{array}$ & 10 & 15 & 21 & 19 & 37 & 45 \\
\hline & $\begin{array}{l}\text { 小红孔菌科 } \\
\text { Pycnoporellaceae }\end{array}$ & $\begin{array}{l}\text { 北温带 } \\
\text { Temperate }\end{array}$ & - & - & 1 & - & - & 1 \\
\hline & $\begin{array}{l}\text { 亚红孔菌科 } \\
\text { Rhodoniaceae }\end{array}$ & $\begin{array}{l}\text { 北温带 } \\
\text { Temperate }\end{array}$ & 1 & - & - & 1 & - & - \\
\hline & $\begin{array}{l}\text { 斯氏菇科 } \\
\text { Steccherinaceae }\end{array}$ & $\begin{array}{l}\text { 世界广布 } \\
\text { Cosmopolitan }\end{array}$ & 1 & 2 & 3 & 2 & 6 & 10 \\
\hline \multirow{2}{*}{$\begin{array}{l}\text { 红菇目 } \\
\text { Russulales }\end{array}$} & 邦氏孔菌科 & 世界广布 & 1 & 1 & 3 & 1 & 1 & 3 \\
\hline & $\begin{array}{l}\text { Bondarzewiaceae } \\
\text { 猴头菌科 } \\
\text { Hericiaceae }\end{array}$ & $\begin{array}{l}\text { Cosmopolitan } \\
\text { 北温带 } \\
\text { Temperate }\end{array}$ & - & - & 1 & - & - & 3 \\
\hline $\begin{array}{l}\text { 䊁孢孔菌目 } \\
\text { Trechisporales }\end{array}$ & $\begin{array}{l}\text { 刺狍孔菌科 } \\
\text { Hydnodontaceae }\end{array}$ & $\begin{array}{l}\text { 世界广布 } \\
\text { Cosmopolitan }\end{array}$ & 1 & - & - & 1 & - & - \\
\hline
\end{tabular}


表2 三个山脉被子植物和裸子植物上的多孔菌物种丰富度比较

Table 2 Species richness of polypores on angiosperm and gymnosperm wood in the three mountain ranges

\begin{tabular}{|c|c|c|c|c|}
\hline 寄主类型 & Type of host & 阿尔泰山脉 Altay Mountains & 秦岭山脉 Qinling Mountains & 南岭山脉 Nanling Mountains \\
\hline 被子植物 & Angiosperm & $30(35.7 \%)$ & $86(65.2 \%)$ & $113(70.6 \%)$ \\
\hline 裸子植物 & Gymnosperm & $36(42.9 \%)$ & 17 (12.9\%) & $14(8.8 \%)$ \\
\hline 两者均可 & Both of angiosperm and gymnosperm & $18(21.4 \%)$ & 29 (21.9\%) & 27 (16.9\%) \\
\hline
\end{tabular}

A 南岭山脉 Nanling Mountains

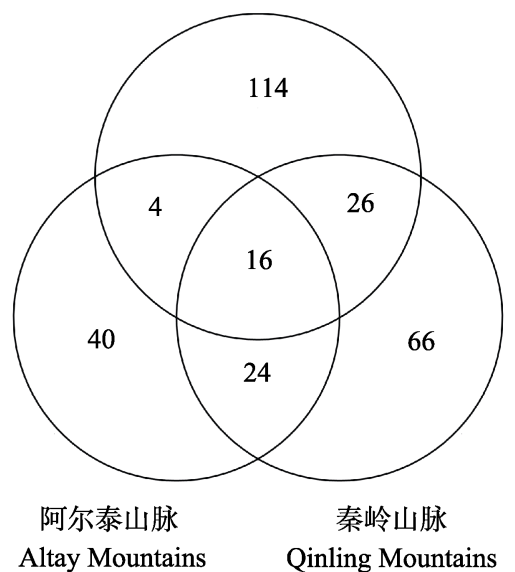

B

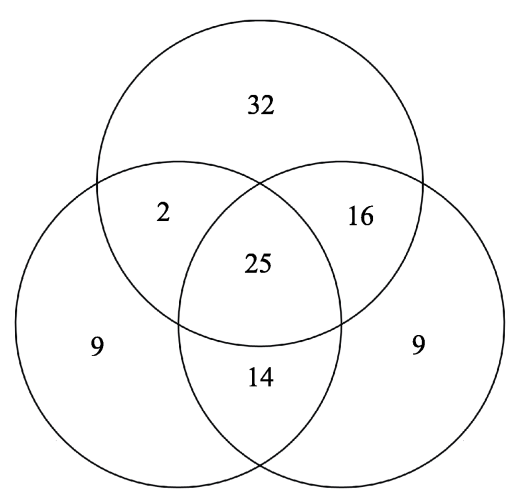

阿尔泰山脉

Altay Mountains
秦岭山脉

Qinling Mountains

图1 三个山脉多孔菌种属数量的韦恩图。(A)物种数; (B)属数。

Fig. 1 Venn diagram of species and generic diversities of polypores in the three mountain ranges. (A) Species numbers; (B) Genus numbers.
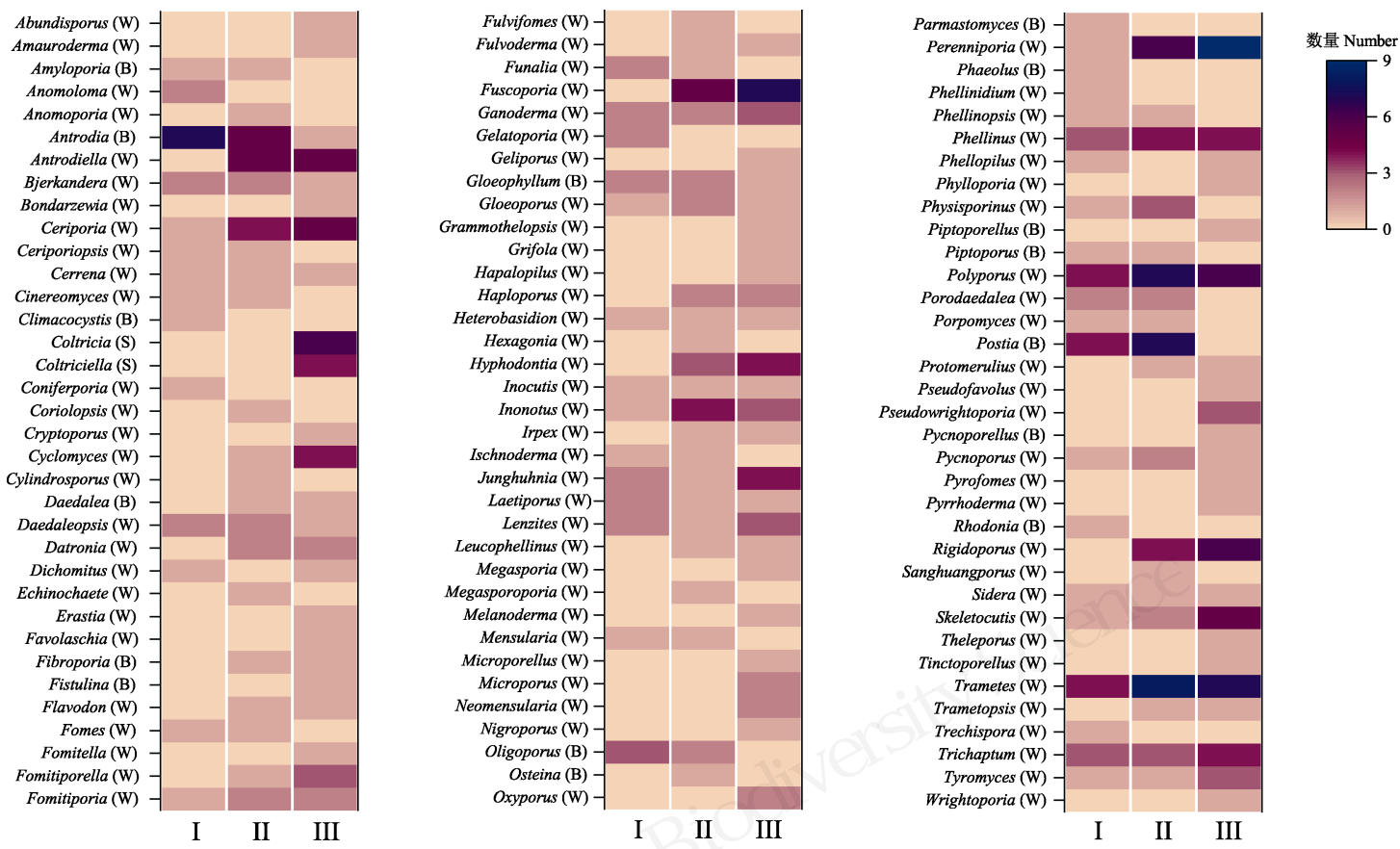

图2 三个山脉多孔菌的属多样性和腐朽类型。(I)阿尔泰山脉; (II)秦岭山脉; (III)南岭山脉; (W)白色腐朽; (B)褐色腐朽; 数量: 每个多孔菌属中包含种的数量。

Fig. 2 The generic diversity and rotting types of polypores in three mountain ranges. (I) Altay Mountains; (II) Qinling Mountains; (III) Nanling Mountains; (W) White rot; (B) Brown rot; Number: The species numbers of genus. 


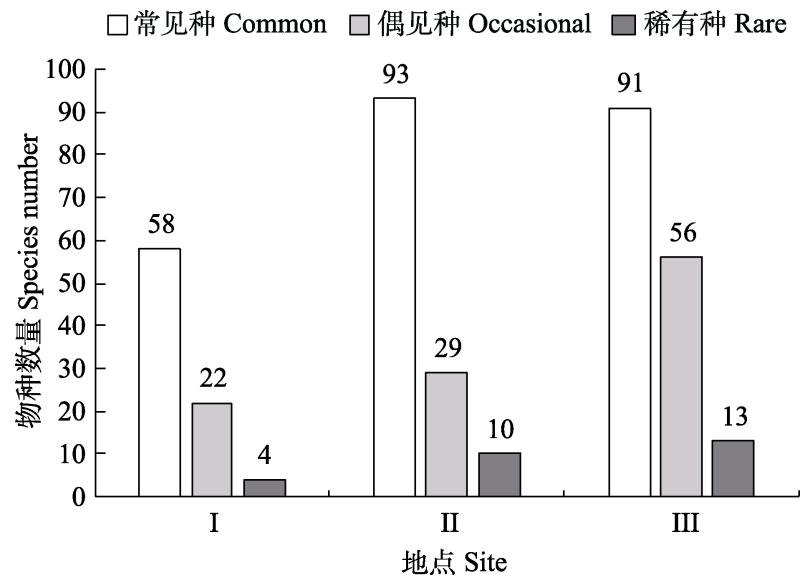

图3 三个山脉多孔菌种类出现频度。(I)阿尔泰山脉; (II)秦 岭山脉; (III)南岭山脉。

Fig. 3 Comparison of the occurrence frequencies of polypores in the three mountain ranges. (I) Altay Mountains; (II) Qinling Mountains; (III) Nanling Mountains.

\section{4 多孔菌区系地理成分}

\subsection{1 科的地理成分}

多孔菌的科的地理分布类型分析表明(表1), 阿尔泰山脉有世界广布成分 13 科, 北温带分布成分 5 科; 秦岭的世界广布成分和北温带成分分别为 14 科和7科; 南岭有世界广布成分 14 科; 北温带分布 成分6科，热带亚热带成分 2 科。

\subsection{2 属的地理成分}

比较三个山脉的多孔菌属的地理成分，阿尔泰 山脉世界广布属27个(占该山脉属的54\%), 北温带 分布属22个(44\%), 东亚分布属1个(2\%), 没有泛热 带分布属和热带亚洲分布属; 秦岭的世界广布属、 北温带分布属、泛热带、热带亚洲分布属和东亚分 布属分别为33个(51.7\%)、19个(29.7\%)、9个(14.1\%)、 1 个 $(1.5 \%)$ 和 2 个 $(3 \%)$ 。南岭山脉的世界广布属、北 温带分布属、泛热带属、热带亚洲分布属和东亚分 布属分别为 40 个、 13 个、 18 个、 2 个和 2 个, 所占比 例依次为 $53.3 \% 、 17.3 \% 、 24 \% 、 2.7 \%$ 和 $2.7 \%$ 。可见, 三个山脉的多孔菌种类均以世界广布属为主。从寒 温带至亚热带, 北温带分布属的比例逐渐下降, 而 泛热带分布属和热带亚洲分布属的比例逐渐升高。

\section{3 讨论}

本文对我国从西北到东南的寒温带至亚热带 的阿尔泰山脉、秦岭山脉和南岭山脉的多孔菌种群 分布特征、生态习性和区系组成进行比较, 发现分 布在不同气候带的三个山脉的多孔菌在物种多样
性、寄主选择性和腐朽类型等方面均表现出了明显 的地域差异: 从寒温带至亚热带, 多孔菌物种多样 性总体呈现逐渐升高的趋势, 特有种比例也逐渐升 高; 寄主的偏好性从寒温带至亚热带由裸子植物为 主转换为被子植物; 白色腐朽菌的种类始终高于 褐色腐朽菌, 且白色腐朽菌的种数从寒温带至亚 热带逐渐增加, 而褐色腐朽菌逐渐降低; 在分布 频次上, 虽然总体上具有相似性, 但稀有种和偶 见种的数量从寒温带至亚热带逐渐增多。

造成上述现象的原因与各山脉所处的气候条 件和森林植被类型相关，其中温度和降水同时影响 着多孔菌及其寄主植物的分布。阿尔泰山脉、秦岭、 南岭分属于三个不同的气候带, 随着温度和降水量 的逐渐升高, 植物的物种丰富度和特有种类也随之 增加, 为多孔菌提供了更为多样的生长基质，从而 增加了多孔菌的物种多样性和特有种的发生几率。 在林型方面, 多孔菌更喜生于针阔混交林中, 在纯 针叶林或阔叶林中种类相对较少(赵继鼎和张小青, 1994), 因而各山脉植物物种多样性的高低是影响 多孔菌分布的重要因素。阿尔泰山脉属于温带大陆 性季风气候, 主要树种多为适应冷湿气候的针叶树 种, 组成比较单一, 由于有些多孔菌对寄主具有一 定的选择性甚至专一性，造成该地区的多孔菌物种 多样性比秦岭和南岭低且更偏好生长在裸子植物 上(陈文俐和杨昌友, 2000; Gilbert et al, 2008)。秦岭 山脉和南岭山脉分别位于中国中部和东南部, 气候 较为湿润, 温度也相对较高, 以阔叶树种为主, 且 树种组成丰富，更适于多孔菌的生长，因而秦岭、 南岭两个地区的多孔菌物种多样性较高, 且寄主多 为被子植物, 其中, 南岭山脉偏好被子植物的多孔 菌种类超过该地区多孔菌物种总数的 $85 \%$ 。

区系地理分析发现，三个山脉的多孔菌种类均 以世界广布属为主, 其中, 阿尔泰山脉和秦岭山脉 以世界广布成分和北温带成分为主，南岭以世界广 布和泛热带成分为主。从寒温带至亚热带, 北温带 分布属的比例逐渐降低, 而泛热带分布属和热带分 布属的比例逐渐升高，这与 3 个区域的气候、植被及 多孔菌的适应性有关。其中温度和湿度是影响多孔 菌孢子萌发和菌丝发育的重要因素, 研究表明大多 数多孔菌的生长适宜温度在 $25-30^{\circ} \mathrm{C}$ 之间, 当温度 低于 $15^{\circ} \mathrm{C}$ 时许多种类的生长受到抑制。从寒温带至 
亚热带, 多孔菌种类随着温度、降水量的逐渐增加 而增加(赵继鼎和张小青, 1994)。阿尔泰山脉气候寒 冷干燥, 不利于多孔菌的孢子萌发和子实体生长, 分布的种类多是适应能力强、分布范围广的物种, 即世界广布属和北温带分布属, 这与该地区的植物 区系成分相一致。秦岭山脉为温带与亚热带过渡区, 是中国气候上的南北分界线, 气温、降水量均处于 适中水平, 故多孔菌种类在以世界广布属和北温带 分布属为主的基础上, 泛热带、热带分布属的比例 也有所增加, 这与该地区植物以北温带分布属为主 (占总属数的 $31.16 \%$ )相一致 ${ }^{11}$ 。而南岭位于中国东南 部, 该地区主要为亚热带阔叶林, 植物种类非常丰 富, 多孔菌种类以世界广布和泛热带成分为主, 这 与该地区的植物区系地理成分较为一致。

\section{ORCID}

武英达 (D) https://orcid.org/0000-0003-1295-4015

芗卫琳 (iD https://orcid.org/0000-0002-0888-0351

员瑗 (iD https://orcid.org/0000-0001-6674-9848

\section{参考文献}

Asiegbu FO, Nahalkova J, Li GS (2005) Pathogen-inducible cDNAs from the interaction of the root rot fungus Heterobasidion annosum with Scots pine (Pinus sylvestris L.). Plant Science, 168, 365-372.

Baldrian P, Lindahl B (2011) Decomposition in forest ecosystems: After decades of research still novel findings. Fungal Ecology, 4, 359-361.

Bau T, Li Y (2000) Fungal community diversity in Daqinggou Nature Reserve. Acta Ecologica Sinica, 20, 986-991. (in Chinese with English abstract) [图力古尔, 李玉 (2000) 大 青沟自然保护区大型真菌群落多样性研究. 生态学报, 20, 986-991.]

Bian LS, Dai YC (2015) Mycota and ecology of polypores in eastern Himalayas. Acta Ecologica Sinica, 35, 1554-1563. (in Chinese with English abstract) [边禄森, 戴玉成 (2015) 东喜马拉雅地区多孔菌区系和生态习性. 生态学报, 35, 1554-1563.]

Cao QM, Yin LK, Chen YF, Yang ML, Yang GQ (2015) Analysis on characteristics of flora in south slope of Altai Mountain. Acta Botanica Boreali-Occidentalia Sinica, 35, 1460-1469. (in Chinese with English abstract) [曹秋梅, 尹 林克, 陈艳锋, 杨美琳, 杨更强 (2015) 阿尔泰山南坡种 子植物区系特点分析. 西北植物学报, 35, 1460-1469.]

Cao Y, Wu SH, Dai YC (2012) Species clarification of the prize medicinal Ganoderma mushroom “Lingzhi”. Fungal

(1) 杨晓俊 (2016) 太白山自然保护区植物区系特征及其多样性保护对 策. 硕士学位论文, 西北农林科技大学, 杨凌.
Diversity, 56, 49-62.

Chen WL, Yang CY (2000) A floristic study on the seed plant in Mts. Altay of China. Acta Botanica Yunnanica, 22, 371-378. (in Chinese with English abstract) [陈文俐, 杨昌 友 (2000) 中国阿尔泰山种子植物区系研究. 云南植物 研究, 22, 371-378.]

Cui BK, Wei YL, Dai YC (2006) Polypores from Zijin Mountain, Jiangsu Province. Mycosystema, 25, 9-14. [崔宝 凯, 魏玉莲, 戴玉成 (2006) 江苏紫金山的多孔菌. 菌物 学报, 25, 9-14.]

Dai YC (2010) Hymenochaetaceae (Basidiomycota) in China. Fungal Diversity, 45, 131-343.

Dai YC (2012) Pathogenic wood-decaying fungi on woody plants in China. Mycosystema, 31, 493-509. (in Chinese with English abstract) [戴玉成 (2012) 中国木本植物病原 木材腐朽菌研究. 菌物学报, 31, 493-509.]

Dai YC (2012) Polypore diversity in China with an annotated checklist of Chinese polypores. Mycoscience, 53, 49-80.

Dai YC, Bau T, Cui BK, Qin GF (2013) Illustrations of Medicinal Fungi in China. Northeast Forestry University Press, Harbin. (in Chinese) [戴玉成, 图力古尔, 崔宝凯, 秦国夫 (2013) 中国药用真菌图志. 东北林业大学出版 社, 哈尔滨.]

Dai YC, Cui BK, Yuan HS, Li BD (2007) Pathogenic wooddecaying fungi in China. Forest Pathology, 37, 105-120.

Dai YC, Yang ZL (2008) A revised checklist of medicinal fungi in China. Mycosystema, 27, 801-824. (in Chinese with English abstract) [戴玉成, 杨祝良 (2008) 中国药用 真菌名录及部分名称的修订. 菌物学报, 27, 801-824.]

Dai YC, Yang ZL, Cui BK, Wu G, Yuan HS, Zhou LW, He SH, Ge ZW, Wu F, Wei YL, Yuan Y, Si J (2021) Diversity and systematics of the important macrofungi in Chinese forests. Mycosystema, 40, 770-805. (in Chinese with English abstract) [戴玉成, 杨祝良, 崔宝凯, 吴刚, 袁海 生, 周丽伟, 何双辉, 葛再伟, 吴芳, 魏玉莲, 员瑗, 司静 (2021) 中国森林大型真菌重要类群多样性和系统学研 究. 菌物学报, 40, 770-805.]

Dai YC, Yuan HS, He W, Decock C (2006) Polypores from Beijing area, northern China. Mycosystema, 25, 368-373. [戴玉成, 袁海生, 贺伟, Decock C (2006) 中国 北京地区的多孔菌. 菌物学报, 25, 368-373.]

Dai YC, Zhou LW, Yang ZL, Wen HA, Bao T, Li TH (2010) A revised checklist of edible fungi in China. Mycosystema, 29, 1-21. (in Chinese with English abstract) [戴玉成, 周丽伟, 杨祝良, 文华安, 图力古尔, 李泰辉 (2010) 中国食用菌 名录. 菌物学报, 29, 1-21.]

Dong AQ, Chen L, Wang FG, Xing FW (2012) Study on vegetation of Nanling National Nature Reserve in Guangdong Province. Journal of Zhongkai University of Agriculture and Engineering, 25(2), 1-7. (in Chinese with English abstract) [董安强, 陈林, 王发国, 邢福武 (2012) 广东南岭国家级自然保护区的植被研究. 仲恺农业工程 学院学报, 25(2), 1-7.]

Floudas D, Binder M, Riley R, Barry K, Blanchette RA, Henrissat B, Martínez AT, Otillar R, Spatafora JW, Yadav 
JS, Aerts A, Benoit I, Boyd A, Carlson A, Copeland A, Coutinho PM, de Vries RP, Ferreira P, Findley K, Foster B, Gaskell J, Glotzer D, Górecki P, Heitman J, Hesse C, Hori C, Igarashi K, Jurgens JA, Kallen N, Kersten P, Kohler A, Kües U, Kumar TKA, Kuo A, LaButti K, Larrondo LF, Lindquist E, Ling A, Lombard V, Lucas S, Lundell T, Martin R, McLaughlin DJ, Morgenstern I, Morin E, Murat C, Nagy LG, Nolan M, Ohm RA, Patyshakuliyeva A, Rokas A, Ruiz-Dueñas FJ, Sabat G, Salamov A, Samejima M, Schmutz J, Slot JC, St John F, Stenlid J, Sun H, Sun S, Syed K, Tsang A, Wiebenga A, Young D, Pisabarro A, Eastwood DC, Martin F, Cullen D, Grigoriev IV, Hibbett DS (2012) The Paleozoic origin of enzymatic lignin decomposition reconstructed from 31 fungal genomes. Science, 336, 1715-1719.

Gilbert GS, Gorospe J, Ryvarden L (2008) Host and habitat preferences of polypore fungi in Micronesian tropical flooded forests. Mycological Research, 112, 674-680.

Hu SS, Ma JY, Shugart HH, Yan XD (2018) Evaluating the impacts of slope aspect on forest dynamic succession in Northwest China based on FAREAST model. Environmental Research Letters, 13, 34027.

Li HJ, Cui BK, Dai YC (2014) Taxonomy and multi-gene phylogeny of Datronia (Polyporales, Basidiomycota). Persoonia, 32, 170-182.

Li Y, Tolgor (2010) Study on fungal flora diversity in Daqinggou Nature Reserve. Chinese Biodiversity, 8, 73-80. (in Chinese with English abstract) [图力古尔, 李玉 (2000) 大青沟自然保护区大型真菌区系多样性的研究. 生物多 样性, 8, 73-80.]

Ma XP (2015) The Timberline of Qinling Mountains and Its Response to Climate Change. PhD dissertation, Northwest University, Xi'an. (in Chinese with English abstract) [马新 萍 (2015) 秦岭林线及其对气候变化的响应. 博士学位 论文, 西北大学, 西安.]

Miao SY, Huang JL, Liu C (2020) Plant diversity and its conservation values of Guangdong Nanling National Park. Guangdong Landscape Architecture, 42(5), 8-11. (in Chinese with English abstract) [缪绅裕, 黄金玲, 刘闯 (2020) 广东南岭国家公园植物多样性及其保护价值. 广 东园林, 42(5), 8-11.]

Ryvarden L, Gilbertson RL (1993) European polypores. Synopsis Fungorum, 6, 1-741.

Song B, Deng WQ, Zhang M, Li TH (2018) The macrofungal diversity in the Nanling Mountains. Tropical Geography, 38, 312-320. (in Chinese with English abstract) [宋斌, 邓旺秋, 张明, 李泰辉 (2018) 南岭大型真菌多样性. 热带地理, 38, 312-320.]

Wang H, Qian K, Si J, Cui BK (2021) Research advances on polysaccharides from Sanghuang. Mycosystema, 40, 895-911. (in Chinese with English abstract) [王豪, 钱坤, 司静, 崔宝凯 (2021) 桑黄类真菌多糖研究进展. 菌物学 报, 40, 895-911.]

Wang XY, Wei YL (2015) Population difference of polypores in northwest and southeast of China. Chinese Journal of Applied Ecology, 26, 3160-3166. (in Chinese with English abstract) [王小燕, 魏玉莲 (2015) 我国西北和东南地区 多孔菌种群差异. 应用生态学报, 26, 3160-3166.]

Wei YL, Dai YC (2004) Ecological function of wood-inhabiting fungi in forest ecosystem. Chinese Journal of Applied Ecology, 15, 1935-1938. (in Chinese with English abstract) [魏玉莲, 戴玉成 (2004) 木材腐朽菌在 森林生态系统中的功能. 应用生态学报, 15, 1935-1938.]

Wu F, Yuan HS, Zhou LW, Yuan Y, Cui BK, Dai YC (2020) Polypore diversity in South China. Mycosystema, 39, 653-681.

Ye XP, Yu XP, Yu CQ, Tayibazhaer AT, Xu FJ, Skidmore AK, Wang TJ (2018) Impacts of future climate and land cover changes on threatened mammals in the semi-arid Chinese Altai Mountains. Science of the Total Environment, 612, 775-787.

Yue M (2015) The vertical bands of plants in Qinling Mountains are complete and complex. Forest \& Humankind, (2), 76-81. (in Chinese) [岳明 (2015) 秦岭植物垂直带谱 完整复杂. 森林与人类, (2), 76-81.]

Zhao JD, Zhang XQ (1994) Ecology, distribution and resources of polypores in China. Acta Ecologica Sinica, 14, 437-443. (in Chinese with English abstract) [赵继鼎, 张小青 (1994) 中国多孔菌类群真菌生态、分布与资源. 生态学报, 14 , 437-443.]

Zhao T, Bai HY, Deng CH, Meng Q, Guo SZ, Qi GZ (2019) Topographic differentiation effect on vegetation cover in the Qinling Mountains from 2000 to 2016. Acta Ecologica Sinica, 39, 4499-4509. (in Chinese with English abstract) [赵婷, 白红英, 邓晨晖, 孟清, 郭少壮, 齐贵增 (2019) 2000-2016年秦岭山地植被覆盖变化地形分异效应. 生态 学报, 39, 4499-4509.]

Zhou LW, Hao ZQ, Wang Z, Wang B, Dai YC (2011) Comparison of ecological patterns of polypores in three forest zones in China. Mycology, 2, 260-275.

Zhou LW, Dai YC (2013) Chinese polypore diversities: Species, mycota and ecological functions. Biodiversity Science, 21, 499-506. (in Chinese with English abstract) [周 丽伟, 戴玉成 (2013) 中国多孔菌多样性初探: 物种、区 系和生态功能. 生物多样性, 21, 499-506.]

(责任编委：郭良栋 责任编辑：时意专)

附录1 三个山脉的多孔菌名录

\section{附录 Supplementary Material}

Appendix 1 An annotated checklist of polypores in the three mountain ranges https://www.biodiversity-science.net/fileup/PDF/2021094-1.xlsx 